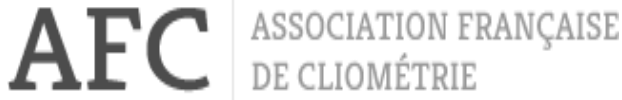

\section{WORKING PAPERS}

Nr. 6, 2013

The Foundations of Female

Empowerment Revisited

Claude DIEBOLT, Faustine PERRIN 


\title{
The Foundations of Female Empowerment Revisited
}

\author{
Claude DIEBOLT and Faustine PERRIN*
}

\begin{abstract}
This paper lays the foundations of the analysis of the relationship between gender equality and economic growth. The study of this long-run relationship aims at providing a better understanding of the mechanisms and determinants underpinning the development process which allowed economies to move out of a long period of stagnation into a state of sustainable economic growth. Our scientific objective is to check the validity of the central hypothesis that improving gender equality is a key ingredient of the demographic transition and of the process of socio-economic development.
\end{abstract}

Keywords: Cliometrics $•$ Economic Growth $\bullet$ Demographic Transition $•$ Human Capital $\bullet$ Gender JEL Classification: J1, N3, 04

Résumé. - Ce article pose les fondements de l'analyse de la relation entre l'égalité hommes-femmes et la croissance économique. Par l'étude de cette relation de long-terme, notre recherche vise à fournir une meilleure compréhension des déterminants et des mécanismes sous-jacents au processus de développement qui a permis aux économies de sortir d'une longue période de stagnation, pour engager un état de croissance économique soutenue. L'objectif scientifique est précisément de vérifier la validité de l'hypothèse selon laquelle l'égalité hommes-femmes est un ingrédient clef de la transition démographique et du processus de développement socio-économique en général.

Mots-clés: Cliométrie $•$ Croissance économique $・$ Transition démographique $•$ Capital Humain $•$ Genre Classification JEL: J1, N3, 04

* Diebolt: Directeur de Recherche au CNRS, BETA/CNRS (UMR 7522), Université de Strasbourg, 61 avenue de la Forêt Noire, France (e-mail: cdiebolt@unistra.fr); Perrin: Doctorante, BETA/CNRS (UMR 7522), Université de Strasbourg, 61 avenue de la Forêt Noire, France (e-mail: faustine.perrin@unistra.fr). Any and all errors and omissions are our own. Financial support from the University of Strasbourg Institute for Advanced Study (USIAS) and the Bureau d'Économie Théorique et Appliquée (BETA) is gratefully acknowledged. 


\section{Introduction}

Gender equality is not just a women issue. It concerns the society as a whole. The promotion of gender equality together with economic and social empowerment of women is essential to achieve sustainable development. By removing barriers that prevent women from accessing - the same way as men - to human capital endowments, economic opportunities and human rights, the recognition of gender equality afford economies to result in better economic performance and to improve economic development. The principle of achieving equality between men and women is widely recognized today. Promoting gender equality and women empowerment hence became the third Millennium Development Goal adopted by the United Nations member states in 2000.

Although gender equality may not be confidently considered as a causal factor driving economic development, there is persistent cross-country positive relationship between the gender gap index (GGI) and the human development index (HDI). Similarly, we observe persistent negative relationship between the GGI and the total fertility rate (TFR). Figure 1 plots the relationship between the GGI and the HDI, and between the GGI and the TFR, for 114 countries in 2006.

Figure 1 : Relation of Gender Gap Index with Human Development Index and Total Fertility Rate in 2006
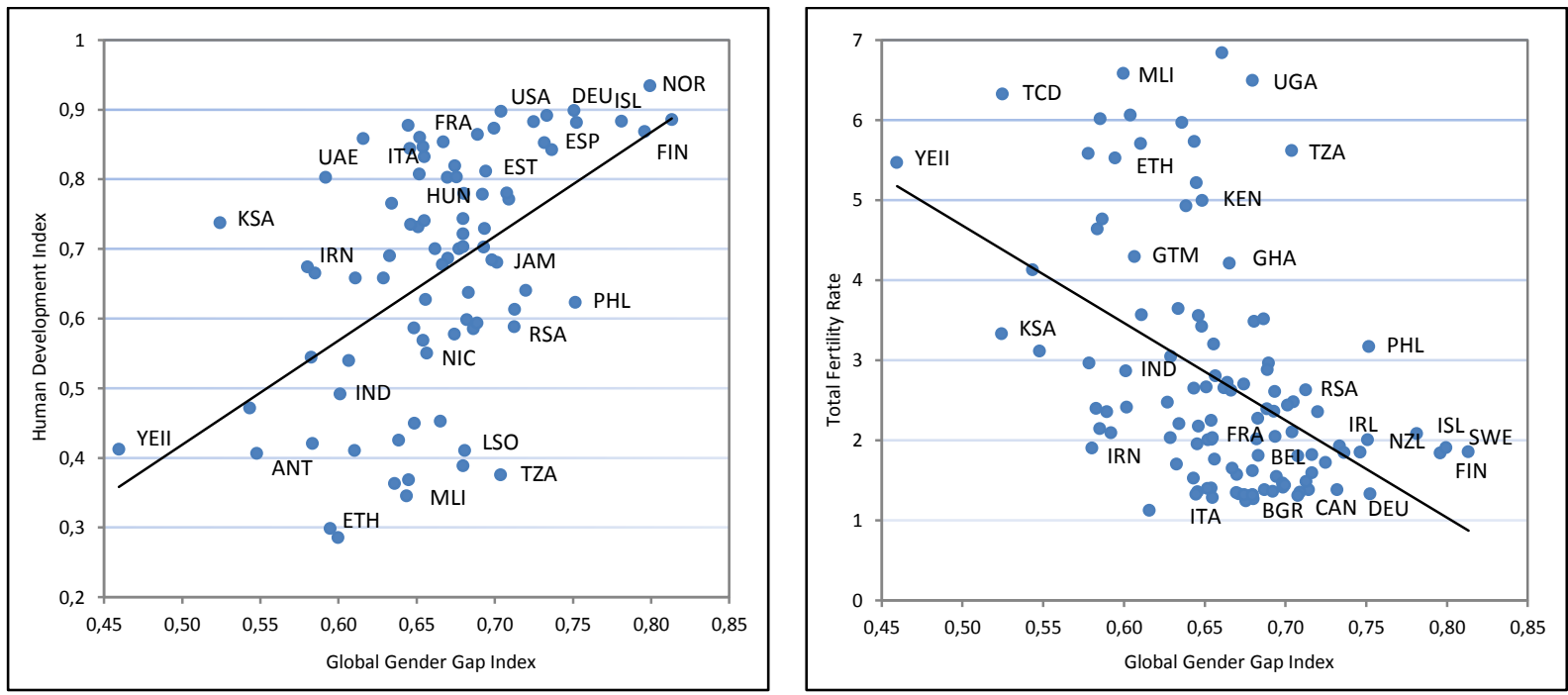

Source: World Bank

Note: Data are available for 114 countries.

The cross-country plots show a positive correlation of 0.55 between gender equality and human development; and a negative correlation of -0.48 between gender equality and fertility. Hence, countries displaying a strong level of equality between genders tend to have a high level of human development and low fertility rates. This is the case of the OECD countries such as Australia, Canada, Denmark, Finland, Germany, Iceland, New Zealand, Norway and Sweden - located on the upper right part of the scatter plot (with HDI around 0.8, GGI above 0.7 and TFR below 2.1). Conversely, 
countries characterized by large gender inequalities exhibit a weaker development index and larger fertility rates. This is the case of countries such as Afghanistan, Angola, Ethiopia, Mali, Nigeria, Yemen and Zambia - located in the lower left part of the scatter plot (with HDI below 0.6, GGI between 0.46 and 0.64 and TFR above 5).

Why had some countries developed faster than others? Why had some countries failed to generate sustained economic growth? Did gender equality improve economic development and trigger the fertility transition? Did causality operate in the opposite direction, from economic development and fertility transition to gender equality? What are the underlying mechanisms behind these relations?

Our paper is fueled by the conviction that, to understand the divergence of economic development across countries today (and more specifically the contemporary growth process of less developed countries), it is necessary to explore the fundamental factors that have contributed to generate growth in higher income countries. In addition, we note that inequalities between men and women seem to be rooted in the cultural, social and political systems of many countries. Hence, we choose to come back to the genesis of the relationship between gender equality, human development and fertility in order to identify the forces that have triggered the take-off from the stagnation of income per capita to sustained economic growth (Galor, 2011, 2012), and to provide a global understanding of the entire process of development. Although our incentive is to understand the process of development as a whole, particular attention is paid to the French case. France is an interesting case study: first, it has received little attention so far; second, it constitutes the first clear evidence of fertility decline in Europe.

Central to this paper is the consideration that the development process is linked with the changing economic role of women. We argue that the deployment of women from the home to the market place has been a necessary precondition to achieve sustained economic growth. Our hypothesis is that women empowerment has played a key and necessary role in the transition toward modern societies through its essential role on the accumulation of human capital and in the fertility transition.

\section{The Transformations of the French Profile}

Throughout most of human existence, societies have been characterized by the stagnation of living standards around a subsistence level. The rise in living standards from the late $18^{\text {th }}$ century in Western countries considerably transformed the profile of society. ${ }^{1}$ Economic growth is just one aspect of the

\footnotetext{
${ }^{1}$ Economic historians disagree on the timing of the transition. Nuvolari and Ricci (2013) recently dated back the beginning of the process of modern economic growth in the English economy at the end of the $18^{\text {th }}$ century but identified a "Smithianphase" of positive economic growth preceding the industrial revolution.
} 
development process. Numerous changes have occurred at the same time of the unprecedented rise in the production of wealth.

Economic Growth. - After a substantially flat evolution during centuries, the per capita income displayed a sudden and brutal increase, following a "hockey stick" shape. Figure 2(a) presents the evolution of the Gross Domestic Product (GDP) per capita in France between 1740 and 2008. From about 1200 dollars (1990 international dollars) in 1800, it reached 22246 dollars in 2008. This impressive rise in GDP per capita is just one aspect of drastic changes that have characterized the evolution of France (and more generally of Western countries) over the past two hundred years. Simultaneously to the improvement in living standards, the Western world witnessed considerable socio-economic, demographic and cultural upheavals that have marked a turning point in economic history and demographic developments.

Demographics. - A set of demographic changes occurred at the same time of the transition from economic stagnation to sustained growth. Coupled with improvements in life expectancy, both mortality and fertility rates declined sharply within the space of two centuries, the so-called demographic transition (Figure 2(b)). Despite an overall increase in the availability of resources, the number of offspring radically declined. Important transformations have also affected the marriage pattern in France in the course of the demographic transition. We distinguish three main stages in the evolution of marriage practices since the $18^{\text {th }}$ century. First, prior to the French Revolution, marriage practices were characterized by the classical features of the European Marriage Pattern (Hajnal, 1965): a large share of definitive celibacy, marriage at a late age and low frequency of illegitimate fertility. Second, after the French Revolution, the share of definitive celibacy fell sharply, the median age at marriage engaged into an impressive downward path (Figure 2(c)) and illegitimate births rose substantially. Third, an important increase in the median age at marriage to a larger extent for women occurred from the 1960-70's while the number of births outside marriage exploded, so did the share of single individuals. Despite changes in the marriage pattern, fertility declined continuously from the end of the $18^{\text {th }}$ century. The decline in fertility reflects a change in habits with regards to fertility regulation. During a large part of the $18^{\text {th }}$ century, individuals have authentically acted in a Malthusian way accepting more and more late marriage and a larger proportion of definitive celibacy in parallel to the fall in infant mortality in order to maintain a sustainable number of offspring. This may explain why a decline in fertility was not observed before the French Revolution. The decline in the median age at marriage and the decline in the proportion of celibacy together with the decline in fertility suggest rather the adoption of contraceptive behaviors within marriage. Such demographic changes profoundly transformed the structure of the population in France. 
Figure 2 : Transformations of the French Profile during the Development Process
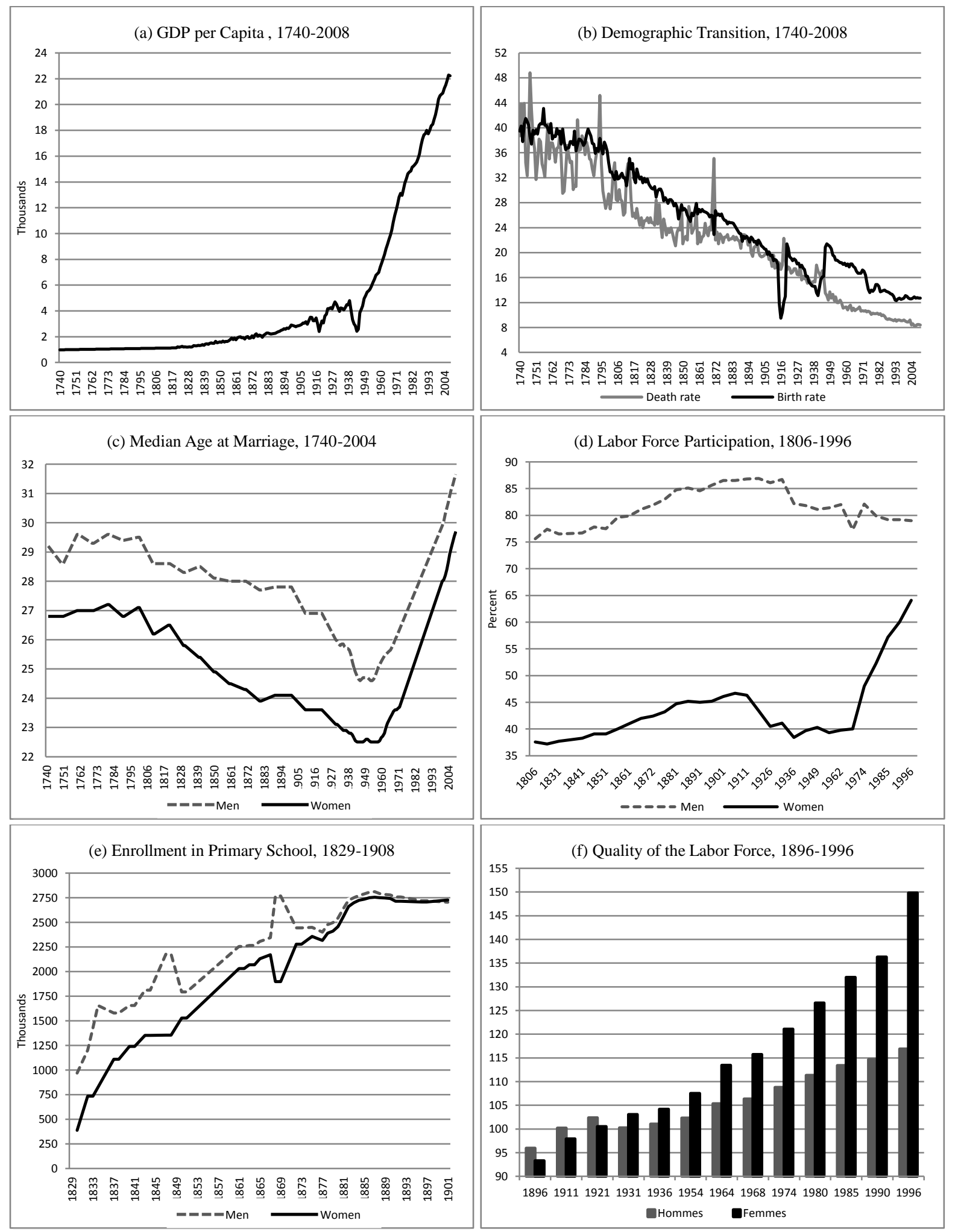

Source: (a) Maddison (2008); (b) Chesnais (1991); (c) Henry and Houdaille (1979) - INSEE; (d) Marchand and Thélot (1997); (e) Diebolt; (f) Own calculations using data from Marchand and Thélot (1997).

Note: Missing values are interpolated by linear interpolation.

Labor Market. - Fertility is linked to the evolution of the labor force. The involvement of women in paid activities increased substantially over time at the same time of changes in its structure. The 
employment moved from agriculture to manufacturing, and then from manufacturing to the tertiary sector. The share of women in the labor force increased significantly from the mid-1 $9^{\text {th }}$ century (Figure 2(d)). This was especially true for married women and for women in childbearing age. Despite a temporary decline during the first half of the $20^{\text {th }}$ century, this upward trend continued at an increasing rate from the 1960's onwards. Conversely, the share of women aged 15-24 in the labor force experienced an important decline. Simultaneously to these profound transformations, the gender gap in occupation and earnings reduced sharply - although differences persisted. These evolutions raise the question of the access to education opportunities.

Education. - The investigation of educational investments reveals strong differences between boys and girls. Women opportunities and access to education were limited and bounded. Over the $19^{\text {th }}$ century, women were on average less trained than men. Nonetheless, formal education became accessible to a vast majority of the population. While a huge share of the population was illiterate in the early $19^{\text {th }}$ century, only a small fraction of the population was still unable to read and write by the end of the century. Women educational investments increased substantially, from primary education (Figure 2(e)) to secondary education and from secondary education to tertiary education. Women became more and more trained. Within a few decades, France experienced an impressive catch-up of girls' enrollment rates over that of boys. The feminization of education allowed girls to fill a large part of their delay in schooling. Hence, the quality of the labor force increased continuously and reversed in favor of women by the early $20^{\text {th }}$ century (Figure $2(\mathrm{f})$ ). ${ }^{2}$ The inability of gender differences in educational investments to explain the persistence of gender differences in occupation and wage questions the socially established roles, behaviors and activities that the society consider appropriate for women.

Gender Relations. - Longitudinal data on educational investments and labor force participation indicate that gender inequalities reduced significantly over the past two hundred years. Women became more educated and more numerous in the labor market. Along these transformations, individuals adapted their behaviors regarding marriage and birth control. During the $19^{\text {th }}$ century, women married younger but had fewer children. All these elements together reveal profound transformations of gender roles and relations along the process of development. Through a long-run evolutionary process, women's status in the social organization of the society evolved significantly (women empowerment). The deployment of women from the home to the market place and their expanded contribution to family income marked unprecedented transformations in women's life and family organization. With the development of market production it became more difficult for women to combine the domestic and professional spheres. Over time, the frontier between the family and the

\footnotetext{
${ }^{2}$ The quality of the labor force is measured as a product of the productivity given to the number of years of schooling and the share of the labor force according to the years of schooling.
} 
professional sphere got thinner. The evolution of family organization shows that a transition has occurred from a sexual division of labor to a more egalitarian distribution of the tasks within the household.

\section{Underlying Mechanisms of the Transition from Stagnation to Sustained Growth}

Empirical regularities produce a complex story and raise numerous questions about the potential interactions between women empowerment, demographic transition and economic development. Insights from economics suggest the role of women to be a strategic variable in economic development. Changes in gender relations do not only concern demographic development but also social and economic development, notably through its effects on the human capital formation of the next generation.

Galor and Weil (2000) emphasize the existence of three stages within the development process based on the evolution of the relationship between income per capita and population growth. During the Malthusian Era (the stagnation), population growth was positively affected by the level of income per capita. The absence of significant changes in the level of technology trapped the income per capita around a subsistence level and population size remained relatively stable. The Post-Malthusian Regime (the take-off) was characterized by a significant increase in the output growth, driven by technological progress, and by an unprecedented increase in population growth. Finally, the Modern Growth Regime (the sustained economic growth) displayed a reversal of the relationship between income per capita and population growth which signed a transition towards a state of sustained economic growth. With the demographic transition the economy abandoned the Malthusian causality between economic growth and population growth, thereby triggering a large increase in living standards.

Could changes in gender relations explain the dramatic reversal of the positive relation between income per capita and population? Would the transition to the Modern Growth Regime have been feasible without women empowerment and improvements in gender equality? What are the underlying behavioral forces behind the process of demographic transition? To what extent and through what mechanisms gender equality affects the decisions taken by the members of the household and acts on long run economic developments?

Understanding the transformation of family organization is essential to explain changes in gender relations but more broadly to explain the social and economic evolutions of the society. There exist three main fundamental functions that family members have to perform: (i) the economic function production of goods and services within and outside the home; (ii) the social function - production of 
education and well-being, transmission of norms and values, inheritance; (iii) the reproductive function - renewal of generations. Family organizations correspond to distinctive historical, sociological and economic models and differ mainly in terms of relative compensation of the time spent performing the different tasks. We distinguish two main types of family organizations: the patriarchal (male-breadwinner) model and the dual-earning model. The system of patriarchal organization of the society divides the work by gender and tends to confine women inside the family in a situation of economic dependency and of subordination to men. This pattern, based on the existence of a demarcation between family and productive activities, results in a division of roles between genders which aims at combining the possibility of having a maximum number of children and income within the household (women at home, men on the labor market). The dual-earning model is characterized by a more egalitarian distribution of the economic function between the members of the household. Both spouses pursue their own professional path, improving the living standard of the household. Women accumulate both paid work in the professional sphere and unpaid work in the private sphere.

In a patriarchal organization of society, the population is positively associated with the income. An increase in the income of the household provides them the necessary resources to bear more children. The subsequent rise in the population induces a decline in income per capita. Ultimately, the output growth fluctuates around a subsistence level (Malthusian stagnation). A change in technological environment increases the returns from education and induces individuals to invest more in education. Human capital being a factor with increasing returns to scale, both output and population growth set on a growing path (Post-Malthusian Regime).

The rise in educational opportunities for girls, the decline in infant mortality as well as the rise in life expectancy during the $19^{\text {th }}$ century contributed to transform family behaviors (in terms of work, demographics or educational investments). Changes in fertility behavior reflect changing costs and benefit from having children. The link between education and fertility is essential to understanding economic and demographic transitions. The rise in women endowment in human capital, during the $19^{\text {th }}$ century, redistributed the power imbalance between genders toward greater equality. It contributed to profoundly modify gender relations and weakened the patriarchal family organization in favor of a more egalitarian distribution of roles within the household. At the same time, the development of the manufacturing sector and cottage industries created a clearer division between the professional and the family sphere.

The emergence of married women into the paid workforce had two effects. On the one hand, it increased the income of the household. On the other hand, the time spent by women on the labor market limited their availability for having and rearing children. As a consequence, it increased the 
cost of childbearing. Having an extra child had therefore a negative effect on the income of the household. The increasing cost of having children for women induced households to limit the number (quantity) of offspring. In parallel, we observe strategies according to which women invest more heavily in human capital through formal education. Maternal endowment in human capital is recognized as being primordial in the educative development of children. Therefore, the rise in women's educational investments impacted positively children's endowment in human capital (quality). Ultimately, women had fewer children but better educated ones. This process triggered a transition from quantity of children to quality of children, the so-called child quantity-quality trade-off (Becker, 1981) at the origin of the accumulation of human capital and of the demographic transition inducing a reversal in the relation between population and output growth (Modern Growth Regime).

\section{Conclusion}

The $19^{\text {th }}$ century experienced numerous socioeconomic, demographic and cultural transformations. As a guideline for all these changes is the evolution in gender relations toward greater equality. The weakening of the patriarchal family model in parallel with the changing socioeconomic role of women explains the transition from a male-breadwinner family organization to a dual-earning model. Major demographic changes have been associated to this transition. The most striking one certainly is the fertility transition. The evolution of the marriage pattern mirrors a convergence in men and women's roles within the household, notably due to the integration of women into market activities. The increase in female investments in education changed deeply the nature of available work for women. The dominant model became the expression of a convergence of male and female behaviors regarding their activity (Maruani, 1996). Hence, women did not stop anymore their professional activity on the occasion of the birth of their children. There was no more choice, neither alternation, but a plurality between family and professional spheres: this was the blossoming of the dual-earning model (also referred to as the gender equity model - Gibling, 1997). Each member of the household pursued a professional career, inducing a higher standard of living but fewer children.

The purpose of our research is located at the crossroads of several areas of economic and social sciences. In order to deepen the analysis of social groups, it is essential to rely on insights from sociologists, demographers, historians and anthropologists, even if our approach remains essentially that of an economist. The cliometric analysis fits perfectly the study of the long-run relationship between women empowerment and development process. Literally, cliometrics is defined as a projection of quantitative social science in the past, structured by economic theory and informed by statistical and econometric tools. That cliometrics is an indispensable tool in the study of long run economic growth is no longer a very controversial statement (Goldin, 1995, Diebolt, 2012). This paper that explores the role of gender equality over long-run economic and demographic development path 
of industrialized countries is an illustration of our belief in this principle. We encourage the methodological debate (not a sterile Methodenstreit), the use of economic theory, mathematical model building, and the reliance upon quantification to support analytical frameworks with historical data. Moreover, we stress the use of standard historical knowledge, wie es eigentlich gewesen ist, to suggest new avenues of research as well as the use of statistical theory and econometrics to combine models with data into a single consistent explanation. In so doing, our main ambition is to close the gap between Geisteswissenschaften and Naturwissenschaften, i.e. to move from the historical verstehen or understanding side to the economic erklären or explaining side or, much better, mixing both approaches, facts and stylized facts, for an increased knowledge of the past, present and future economic and social development of developed and developing economies (Diebolt, 2012; Diebolt and Perrin, 2013). 


\section{References}

Becker G.S. (1981), A Treatise on the Family. Cambridge, MA: Harvard University Press.

Chesnais J.C. (1992), The Demographic Transition: Stages, Patterns, and Economic Implications, Oxford: Clarendon Press.Coale A.J., S.C. Watkins (1986), The Decline of Fertility in Europe. Princeton, NJ: Princeton University Press.

Diebolt C. (2012), “The Cliometric Voice”, History of Economic Ideas, Vol. 20, n³, pp. 51-61.

Diebolt C., F. Perrin (2013), "From Stagnation to Sustained Growth: The Role of Female Empowerment", AFC Working Paper, WP2013-4, 68 pages.

Diebolt C., F. Perrin (2013), "From Stagnation to Sustained Growth: The Role of Female Empowerment", American Economic Review, Vol. 103, n 3, pp. 545-549.

Galor O., D.N. Weil (2000), "Population, Technology, and Growth: From Malthusian Stagnation to the Demographic Transition and Beyond", American Economic Review, Vol. 90, n 4, pp. 806828.

Galor O. (2011), Unified Growth Theory, Princeton University Press.

Galor O. (2012), “The Demographic Transition: Causes and Consequences”, Cliometrica, Vol. 6, n 1, pp. $1-28$.

Giblin P. R. (1997), "Marital spirituality: A quantitative study." Journal of Religion and Health, Vol. $36, \mathrm{n}^{\circ} 4$, pp. 333-344.

Goldin C. (1995), "Cliometrics and the Nobel", The Journal of Economic Perspectives, Vol. 9, $\mathrm{n}^{\circ} 2$, pp. 191-208.

Goldin C. (2006), “The Quiet Revolution that Transformed Women's Employment, Education, and Family", American Economic Review, Vol. 96, n 2, pp. 1-21.

Hajnal J. (1965), “European Marriage patterns in Perspective”, in: Glass, D.V. and Eversley.

Henry L., J. Houdaille (1979), "Célibat et âge au mariage aux XVIIIe et XIXe siècles en France : II. Age au premier mariage", Population, Vol. 34, pp. 403-442.

Maddison A. (2008), Statistics on World Population, GDP and Per Capita GDP, 1-2008 AD. http://www.ggdc.net/maddison/Maddison.htm

Marchand O., C. Thélot (1997), Le travail en France, 1800-2000, Nathan.

Maruani M. (1996), "L'emploi féminin à l'ombre du chômage”, Actes de la recherche en sciences sociales, Vol. 115, pp. 48-57.

Nuvolari A., M. Ricci (2013), "Economic Growth in England, 1250-1850: Some New Estimates Using a Demand Side Approach", Rivista di storia economica, Vol. 1, pp. 31-54. 


\title{
WORKING PAPERS DE L'AFC
}

\section{Année 2013}

\author{
WP2013-1 Charlotte LE CHAPELAIN \\ "Cliométrie et Capital humain" \\ WP2013-2 Peter HUXLEY, Tapas MISHRA, Bazoumana OUATTARA, \\ Mamata PARHI \\ "Understanding Determinants of Happiness under \\ Uncertainty" \\ WP2013-3 Nadir ALTINOK, Claude DIEBOLT, Jean-Luc DEMEULEMEESTER \\ "A New International Database on Education Quality: 1965- \\ 2010" \\ WP2013-4 Claude DIEBOLT, Faustine PERRIN \\ "From Stagnation to Sustained Growth: The Role of Female \\ Empowerment" \\ WP2013-5 Thi Hong Van HOANG, Hooi Hooi LEAN, Wing-Keung WONG \\ "Is Gold Good for Portfolio Diversification? A Stochastic \\ Dominance Analysis of the Paris Stock Exchange"
}

WP2013-6 Claude DIEBOLT, Faustine PERRIN

"The Foundations of Female Empowerment Revisited"

La liste complète des Working Papers est disponible sur le site www.cliometrie.org 